\title{
PERANAN BADAN PENYELESAIAN SENGKETA KONSUMEN (BPSK) KOTA PAYAKUMBUH TERHADAP SENGKETA KONSUMEN*
}

\author{
Nedi Rinaldi \\ STIH Putri Maharaja Payakumbuh \\ Jl. Goduang, Bulakan Balai Kandi, Kec. Payakumbuh Barat, Kota Payakumbuh \\ e-mail: nedirinaldi01@gmail.com
}

\begin{abstract}
The Consumer Dispute Settlement Agency (BPSK) as a product of Law Number 8 of 1999 concerning Consumer Protection (UUPK) in conjunction with Decree of the Minister of Industry and Trade Number: 350/MPP/Kep/12/2001 concerning Implementation of Duties and Authorities of abbreviated Consumer Dispute Resolution Bodies BPSK and the Minister of Trade Regulation Number: 06/M-DAG/PER/2/2017, are institutions for resolving consumer disputes outside the court that should be part of efforts to protect consumers (end) categorized as weak when disputing with stronger business actors. The reality to date, BPSK still has many weaknesses and shortcomings. This condition is exacerbated by the growing strength of neoliberalism that affects the global economic system, which is realized or not has occurred in the strong economic control of business actors against the weak (consumers). This research is field research, namely field research with interview techniques to the parties involved that are directly related to the problem the author discussed, namely Payakumbuh City BPSK and aims to examine the efforts that can be done to optimize BPSK as an institution of consumer dispute resolution in outside the court that is fast, useful and meets the value of justice for the consumer community. This paper is based on a study of prime data and secondary data analyzed qualitatively. Based on the results of the study, efforts can be made to optimize Payakumbuh City BPSK which was formed in 2015 based on the Decree of the Minister of Trade of the Republic of Indonesia Number: 646 /M-DAG/Kep/4/2015, dated April 8, 2015 which can help consumers who feel disadvantaged by business actors.
\end{abstract}

Keywords: Protection; Dispute; Consumer; BPSK.

\begin{abstract}
Abstrak
Badan Penyelesaian Sengketa Konsumen (BPSK) sebagai produk Undang-Undang Nomor 8 Tahun 1999 tentang Perlindungan Konsumen (UUPK) jo dengan Keputusan Menteri Perindustrian dan Perdagangan Nomor: 350/MPP/Kep/12/2001 tentang Pelaksanaan Tugas dan Wewenang Badan Penyelesaian Sengketa Konsumen disingkat BPSK serta Peraturan Menteri Perdagangan Nomor: 06/M-DAG/PER/2/2017, merupakan lembaga penyelesaian sengketa konsumen di luar pengadilan yang seharusnya bisa menjadi bagian dari upaya perlindungan konsumen(akhir) yang dikategorikan lemah ketika bersengketa dengan pelaku usaha yang lebih kuat. Realitasnya sampai saat ini, BPSK masih memiliki banyak kelemahan dan kekurangan. Kondisi ini diperparah dengan semakin kuatnya neoliberalisme yang mempengaruhi sistem perekonomian global, yang disadari atau tidak telah terjadi penguasaan perekonomian yang kuat dari pelaku usaha terhadap yang lemah (konsumen). Penelitian yang dilakukan ini bersifat field research yaitu penelitian lapangan dengan teknik wawancara terhadap pihak-pihak yang terkait yang berhubungan langsung dengan masalah yang penulis bahas yaitu BPSK Kota Payakumbuh serta bertujuan untuk mengkaji upaya-upaya yang dapat dilakukan guna mengoptimalisasi BPSK sebagai lembaga penyelesaian sengketa konsumen di luar pengadilan yang cepat, bermanfaat dan memenuhi nilai keadilan bagi masyarakat konsumen. Tulisan ini didasarkan pada kajian terhadap data-data primeir dan data-data sekunder yang dianalisis secara kualitatif. Berdasarkan hasil kajian dapat dikemukakan upaya-upaya optimalisasi BPSK Kota Payakumbuh yang telah dibentuk
\end{abstract}

\footnotetext{
* Naskah diterima: 05 Maret 2019, direvisi: 23 Maret 2019, disetujui untuk terbit: 27 Maret 2019

Doi: $\underline{10.3376 / j \text { ch.v4i2.138 }}$
} 
pada tahun 2015 berdasarkan SK Menteri Perdagangan Riepublik Indonesia Nomor: 646/MDAG/Kep/4/2015, tertanggal 8 April 2015 yang dapat membantu masyarakat konsumen yang merasa dirugikan oleh pelaku usaha.

Kata Kunci: Perlindungan; Sengketa; Konsumen, BPSK.

\section{PENDAHULUAN}

Hukum perlindungan konsumen dewasa ini mendapat cukup perhatian karena menyangkut aturan-aturan guna mensejahterakan masyarakat, bukan saja masyarakat selaku konsumen saja yang mendapat perlindungan namun pelaku usaha juga mempunyai hak yang sama untuk mendapatkan perlindungan, masing-masing ada hak dan kewajiban. Pemerintah berperan mengatur, mengawasi dan mengontrol, sehingga tercipta sistem yang kondusif saling berkaitan satu dengan yang lain dengan demikian tujuan mensejahterakan masyarakat secara luas dapat tercapai (Superry Daniel Sitompul, 2014). Dalam pelaksanaan pembangunan nasional, pekerja mempunyai peranan dan kedudukan penting sebagai pelaku dalam mencapai tujuan pembangunan dan harus dilindungi (Darmayanti, 2018).

Secara normatif peraturan perundangundangan yang mengatur tentang perlindungan konsumen telah dikeluarkan oleh Pemerintah Indonesia yaitu UndangUndang Nomor 8 Tahun 1999, tentang Perlindungan Konsumen disingkat UUPK serta ditambah dengan peraturan lainnya seperti Keputusan Presiden Nomor 18 Tahun 2010, Keputusan Menteri Perindustrian dan Perdagangan Nomor: 350/MPP/Kep/12/2001 tentang Pelaksanaan Tugas dan Wewenang Badan Penyelesaian Sengketa Konsumen disingkat BPSK serta Peraturan Menteri Perdagangan Nomor: 06/MDAG/PER/2/2017, tentang Badan Penyelesaian Sengketa Konsumen namun banyak masyarakat atau konsumen akhir pengguna barang dan atau jasa yang tidak mengetahui dan tidak memanfaatkan lembaga BPSK tersebut untuk meminta keadilan apabila merasa dirugikan oleh pelaku usaha.

Definisi konsumen menurut pasal 1 ayat 2 Undang- Undang Nomor 8 tahun 1999 adalah setiap orang pemakai barang dan/atau jasa yang tersedia dalam masyarakat, baik bagi kepentingan diri sendiri, keluarga, orang lain maupun makhluk hidup lain dan tidak untuk diperdagangkan, tentang Perlindungan Konsumen sedangkan definisi Perlindungan Konsumen menurut Pasal 1 ayat 1 Undang- Undang Nomor 8 tahun 1999 adalah segala upaya yang menjamin kepastian hukum untuk memberi perlindungan kepada konsumen (Sri Turatmiyah, 2016).

Lemahnya posisi konsumen yang merasa dirugikan oleh pelaku usaha, secara hukum mulai di akomodasi dengan lahirnya Undang-Undang Nomor 8 Tahun nya 1999, Tentang Perlindungan Konsumen yaitu dengan dibentuknya adanya suatu badan penyelesaian sengketa konsumen di daerah tingkat II untuk penyelesaian sengketa konsumen diluar pengadilan (Pasal 49 Undang-Undang 
Nedi Rinaldi: Peranan BPSK Kota Payakumbuh Terhadap Sengketa Konsumen

Nomor 8 Tahun 1999, Tentang Perlindungan Konsumen).

BPSK adalah merupakan suatu Badan/Lembaga independent, badan publik yang mempunyai tugas dan wewenang antara lain melaksanakan penanganan dan penyelesaianan sengketa konsumen secara Konsiliasi, Mediasi dan Arbitrase, memberikan konsultasi perlindungan konsumen, melakukan pengawasan terhadap pencantuman klausula baku, melaporkan kepada penyidik umum, menerima pengaduan baik tertulis maupun tidak tertulis, memanggil pelaku usaha yang diduga telah melakukan pelanggaran, memanggil dan menghadirkan saksi serta menjatuhkan sanksi administrative terhadap pelaku usaha yang melanggar (Zainul Akhyar, Harpani Matnuh, 2015).

Undang-Undang Nomor 8 Tahun 1999 Tentang Perlindungan Konsumen mengatur mengenai hak dan kewajiban dari konsumen dan pelaku usaha, tanggungjawab pelaku usaha, pembinaan dan pengawasan pemerintah, penyelesaian sengketa dan sanksi. Namun dalam pelaksanaannya kita lihat masih jauh dari harapan (Faisal, 2018).

Badan Penyelesaian Sengketa Konsumen (BPSK) sebagai lembaga yang menyelesaikan persoalan sengketa konsumen juga diperkuat dengan Keputusan Menteri Perindustrian dan Perdagangan Nomor: 350/MPP/Kep/12/ 2001, Tentang Pelaksanaan Tugas dan Wewenang Badan Penyelesaian Sengketa Konsumen yang menetapkan adanya pembentukan Badan Penyelesaian
Sengketa Konsumen (BPSK) pada Daerah Kabupaten /Kota, hal ini memperlihatkan maksud pembuat Undang-Undang bahwa ada lembaga yang putusan BPSK sebagai badan penyelesaian sengketa konsumen di luar pengadilan ada pada daerah-daerah Kabupaten /Kota.

Bahwa dari rumusan dalam Pasal 49 ayat (1) undang-undang perlindungan konsumen di atas juga menyangkut tugas Badan Penyelesaian Sengketa Konsumen (BPSK) yang berbunyi "Untuk penyelesaian sengketa konsumen di luar pengadilan adalah tugas pokok, sebab masih ada tugas lain dari Badan Penyelesaian Sengketa Konsumen (BPSK), yaitu: memberikan konsultasi perlindungan konsumen, melakukan pengawasan terhadap pencantuman klausula baku, dan menerima pengaduan konsumen atas terjadinya pelanggaran perlindungan konsumen, serta tugas-tugas lainnya yang termaktub dalam pasal 52 Undang-Undang Nomor 8 Tahun 1999, Tentang Perlindungan Konsumen. Undang-Undang Perlindungan konsumen dalam upaya memberdayakan konsumen menuntut hak-haknya terhadap adanya kerugian dari pelaku usaha, menentukan bahwa konsumen dapat mengajukan gugatan kepada pelaku usaha di tempat konsumen yang bersangkutan bertempat tinggal. Upaya pemberdayaan melalui kemudahan menuntut pelaku usaha di tempat tinggal konsumen belum sepenuhnya dapat dilaksanakan. Bagi konsumen yang di daerahnya yang belum dibentuk BPSK, seperti maka bisa dilakukan pada kota tempat BPSK yang 
terdekat berada, kecuali jika konsumen tersebut menuntut pelaku usaha melalui lembaga peradilan umum.

Bahwa untuk diketahui, hambatan yang sudah jelas mempengaruhi penegakan hukum di bidang perlindungan konsumen adalah faktor ekonomi, sarana dan prasarana serta faktor kurangnya pengetahuan konsumen tentang keberadaan lembaga BPSK tersebut.

Pembentukan Badan Penyelesaian Sengketa Konsumen (BPSK) sendiri didasarkan pada adanya kecenderungan masyarakat yang segan untuk beracara di pengadilan karena posisi konsumen yang secara sosial dan finansial tidak seimbang dengan pelaku usaha (Superry Daniel Sitompul dan Januari Siregar, 2014: 2).

Di Kota Payakumbuh keberadaan lembaga BPSK ini telah ada sejak tahun 2015, hal ini ditandai dengan adanya pengangkatan Majelis BPSK Kota Payakumbuh berjumlah 9 (sembilan) orang yang terdiri dari 3 (tiga) orang dari unsur pemerintah 3 (tiga) orang dari unsur pelaku usaha dan 3 (tiga) orang dari unsur konsumen yang di angkat berdasarkan SK Menteri Perdagangan Republik Indonesia Nomor: 646/M-DAG/Kep/4/2015, tertanggal 8 April 2015 serta dibantu oleh 5 (lima) orang sekretariat /panitera yang nota benenya adalah pegawai negeri yang bertugas dibidang perdagangan.

Keberadaan BPSK Kota Payakumbuh yang berkantor di salah satu ruang kantor Dinas Perdagangan Kota Payakumbuh dirasakan sebagai angin segar bagi masyarakat konsumen akhir yang mencari keadilan ketika merasa dirugikan oleh tindakan pelaku usaha yang dinilai agak nakal dalam menjalankan usaha atau bisnisnya namun banyak pula masyarakat Kota Payakumbuh yang tidak tahu adanya keberadaan lembaga BPSK Kota Payakumbuh padahal secara kontinu sekretariat BPSK Kota Payakumbuh telah memberikan sosialisasi baik pada tingkat kecamatan maupun melalui selebaranselebaran maupun melalui mass media radio maupun media tulis/cetak namun hal tersebut dan hal tersebut dalam dilihat dari data-data sengketa konsumen yang telah diputus oleh BPSK Kota Payakumbuh sejak tahun 2016 sampai tahun 2018, telah terjadi penurunan penyelesaian serta sengketa konsumen yang masuk pada tahun 2016 sebanyak 9 (sembilan) kasus yang pada tahun 2018 sengketa konsumen yang masuk sebanyak 2 (dua) kasus padahal untuk menyelesaikan sengketa konsumen tersebut tidak dikenai biaya atau gratis namun pada kenyataan sengketa konsumen yang masuk BPSK Kota Payakumbuh terjadi pernurunan yang cukup signifikan sehingga menjadi bahan evaluasi BPSK Kota Payakumbuh untuk lebih mengakomodir persoalan sengketa konsumen di Kota Payakumbuh karena banyak persoalan konsumen yang sering terjadi yang diduga merugikan konsumen tetapi tidak diselesaikan pada tingkat BPSK karena ketiadaan informasi tentang keberadaan BPSK Kota Payakumbuh.

Berdasarkan uraian -uraian yang telah dikemukakan dalam latar belakang di atas, maka penulis mengidentifikasikan 
permasalahan sebagai berikut: Peranan

BPSK Kota Payakumbuh dalam menjalankan kewenangannya dalam memutus perkara sengketa konsumen dan faktor-faktor yang menyebabkan terjadinya penurunan sengketa yang masuk pada Kantor BPSK Kota Payakumbuh.

\section{METODE PENELITIAN}

Berkaitan dengan penulisan ilmiah ini, Penulis menggunakan metode penelitian hukum yuridis empiris. Hal mana penelitian ini bermaksud untuk memahami dan mencari fakta-fakta yang terjadi pada objek penelitian. Penelitian ini menggunakan data lapangan sebagai data primer dan data sekunder. Selain itu, penelitian ini juga bertujuan untuk memahami arti suatu peristiwa dan kaitan-kaitannya dengan orang-orang yang diberi kewenangan untuk menyelesaikan sengketa antara konsumen dengan pelaku usaha.

\section{HASIL DAN PEMBAHASAN}

\section{Peranan Badan Penyelesaian Sengketa Konsumen (BPSK) Kota Payakumbuh Dalam Menjalankan Kewenangannya Memutus Perkara Sengketa Konsumen}

\begin{tabular}{lccr}
\multicolumn{1}{c}{ Pasal } & 52 & Nomor 8 & Tahun 1999, \\
tentang & Perlindungan & Konsumen \\
dinyatakan & mengenai & tugas dan \\
wewenang & Majelis Badan & Penyelesaian \\
Sengketa Konsumen adalah:
\end{tabular}

a. Melaksanakan penanganan dan penyelesaian sengketa konsumen dengan cara melalui mediasi atau arbitase atau konsiliasi; b. Memberikan konsultasi perlindungan konsumen;

c. Melakukan pengawasan terhadap pencantuman klausula baku;

d. Melaporkan kepada penyidik umum apabila terjadi pelanggaran ketentuan dalam undang-undang ini;

e. Menerima pengaduan baik tertulis maupun tidak tertulis dari konsumen tentang terjadinya pelanggaran terhadap perlindungan konsumen;

f. Melakukan penelitian dan pemeriksaan sengketa perlindungan konsumen;

g. Memanggil pelaku usaha yang diduga telah melakukan pelanggaran terhadap perlindungan konsumen;

h. Memanggil dan menghadirkan saksi, saksi ahli, dan atau setiap orang yang dianggap mengetahui pelanggaran terhadap undangundang ini;

i. Meminta bantuan penyidik untuk menghadirkan pelaku usaha, saksi, saksi ahli, atau setiap orang sebagaimana dimaksud pada huruf $g$ dan huruf $h$, yang tidak bersedia memenuhi panggilan Badan Penyelesaian Sengketa Konsumen;

j. Mendapatkan, meneliti dan/atau menilai surat, dokumen, atau alat bukti lain guna penyelidikan dan atau pemeriksaan;

k. Memutuskan dan menetapkan atau tidak adanya kerugian pihak konsumen;

1. Memberitahukan putusan kepada pelaku usaha yang melakukan pelanggaran terhadap perlindungan konsumen;

m. Menjatuhkan sanksi administratif kepada pelaku usaha yang melanggar ketentuan undangundang ini ( Keputusan Menteri Perindustrian dan Perdagangan Nomor: 350/MPP Kep/12/2001). 
Berdasarkan Pasal 2 Keputusan Presiden Nomor 18 Tahun 2010 dinyatakan: Setiap konsumen yang dirugikan atau ahli waris dapat mengajukan gugatan kepada pelaku usaha di Badan Penyelesaian Sengketa Konsumen (BPSK) tempat berdomisili konsumen atau pada Badan Penyelesaian Sengketa Konsumen (BPSK) terdekat.

Batas Kewenangan BPSK dalam menyelesaikan sengketa konsumen, mempertanyakan apakah BPSK masih punya kewenangan menyelesaikan sengketa konsumen sehubungan dengan perjanjian pembiayaan dengan jasa keuangan (Busyra Azheri, 2018:1) karena Tugas BPSK dalam penyelesaian Sengketa konsumen berdasarkan Pasal 52 UUK jo Pasal 4 Kepmenperindag No. 350/2001, dapat diuraikan sebagai berikut

1. Konsiliasi, upaya mempertemukan para pihak yang bersengketa dan penyelesaiannya diserahkan kepada para pihak.

2. Mediasi, yaitu BPSK sebagai penasehat atau mediator dan penyelesaiannya diserahkan kepada para pihak.

3. Arbitrase, Para pihak yang bersengketa menyerahkan sepenuhnya keputusan penyelesaian sengketa kepada BPSK.

Cara Penyelesaian sengketa konsumen tersebut diatas dilakukan bukan secara berjenjang akan tetapi dilakukan atas pilihan para pihak yang bersengketa dan penyelesaian sengketa konsumen tersebut bisa dikategorikan sebagai penyelesaian yang dikenal dengan istilah Alternatif Dispute Resolution (ADR).

Pengertian Dispute Resolution biasa disebut Alternatif Dispute Resolution adalah serangkaian proses yang bertujuan untuk menyelesaikan sengketa antara pihak-pihak. Pada mulanya penyelesaian sengketa dilihat sebagai suatu alternatif dari keputusan hakim atas suatu keputusan mengenai sengketa menurut hukum (I Made Widyana, 2007: 19).

ADR adalah suatu ungkapan yang digunakan oleh banyak penulis dalam menguraikan perkembangan tekni-teknik penyelesaian sengketa tanpa kepuutsan formal, yang diperoleh melalu arbitrase dan pengadilan. Mekanisme ADR biasanya melibatkan penengah yang adil (tidak memihak) yang bertindak sebagai pihak ketiga atau pihak yang netral (I Made Widyana, 2007: 19).

Penyelesaian sengketa konsumen pada BPSK juga dapat melalui Mediasi (Fahmi Shahab, 2015: 1) Pilihan Penyelesaian Sengketa ada beberapa pilihan :

1. Adjudikatif penyelesaiannya adalah Diselesaikan (diputus) Lembaga, Litigasi: Pengadilan, Non Litigasi: Arbitrase

2. Non Adjudikatif penyelesaiannya adalah diselesaikan para pihak sendiri, Mediasi, Konsiliasi, Konsultasi, Negosiasi, Penilaian ahli, dan lain-lain dan mengapa ada Mediasi/Konsiliasi hal tersebut adalah sebagai

- Konflik bisa tertata; 
- Dipandu oleh pihak ketiga yang indenpenden (mediator)

- Mengarah ke penyelesaian (ke depan);

- Hasil kesepakatan bisa sangat kreatif;

- Kerahasiaan terjaga;

- Hubungan baik terjaga;

- Waktu relatif singkat;

- Biaya efisien;

- Bila mencapai kesepakatan, final.

- Karakteristik Mediasi.

Setiap mediasi memiliki karakteristik (Fahmi Shahab Fahmi Shabab, 2015: 4), yaitu:

- Proses Para pihak yang relevan dan/atau perwakilannya;

- Pihak ketiga yang netral, seorang mediator;

- $\quad$ Upaya untuk mendorong tercapainya kesepakatan.

Pra Mediasi dapat diuraikan sebagai berikut :

1. Penunjukan Mediator;

2. Kesepakatan Untuk Mediasi;

3. Adanya Par Pihak;

4. Persetujuan penjadwalan pertemuan.

Sedangkan Proses Mediasi (Fahmi Shabab, 2015: 5) adalah sebagai berikut:

- Pertemuan Awal;

- Pemetaan masalah dan Persiapan;

- Pertemuan Bersama;

- Pendefinisian masalah dan Penyelesaian Masalah;

- Penyelesaian Kesepakatan dan Tidak Kesepakatan.
Latar belakang Penyelenggaraan Badan Penyelesaian Sengketa Konsumen (BPSK) adalah sebagai berikut

1. Pembangunan hukum yang memberikan perlindungan terhadap konsumen dalam rangka membangun manusia Indonesia seutuhnya yang berlandaskan Pancasila dan UUD 1945.

2. Pembangunan dan pengembangan perekonomian di bidang perindustrian dan perdagangan nasional/internasional telah menghasilkan berbagai variasi barang dan/atau jasa yang ditawarkan/ dipromosikan/di iklankan dan diperdagangkan dengan berbagai cara untuk dapat telah menghasilkan berbagai variasi barang dan/ atau jasa yang ditawarkan/dipromosikan/di iklankan dan diperdagangkan dengan berbagai cara untuk dapat dikonsumsi/dimanfaatkan dan atau dipergunakan oleh konsumen.

3. Globalisasi ekonomi dan liberalisasi perdagangan telah membawa dampak pada derasnya arus masuk barang berasal dari impor baik legal maupun illegal serta meningkatnya persaingan usaha yang cenderung kearah persaingan tidak sehat.

4. Hal tersebut memungkinkan kedudukan pelaku usaha dan konsumen menjadi tidak seimbang di konsumen berada pada posisi yang lemah karena konsumen menjadi obyek untuk meraup keuntungan melalui kiat-kiat promosi, pengiklanan dan cara-cara menjual 
yang kadang ada unsur pemaksaan atau pengelabuhan.

5. Perlunya penegakan hukum untuk melindungi konsumen melalui penyelenggaraan UUPK dan peraturan pelaksanaannya salah satunya adalah melalui pembentukan BPSK di kabupaten/kota (Desemberius, $2016: 1$ ).

Bahwa proses pelaksanaan eksekusi putusan Badan Penyelesaian Sengketa Konsumen (BPSK) di Pengadilan Negeri (Fahmiron, 2018: 1), mengenai prosedur permohonan eksekusi tidak diatur secara rinci dan jelas dalam Undang-Undang Perlindungan Konsumen Pasal 57 menyatakan bahwa putusan majelis BPSK di mintakan penetapan eksekusinya kepada Pengadilan Negeri ditempat konsumen dirugikan. Kemudian ketentuan Pasal 57 Undang-Undang Perlindungan Konsumen ini juga diperjelas dengan Pasal 42 Kepmenperindag No. 350/MMP/12/2001 bahwa pihak yang mengajukan eksekusi adalah BPSK.

Bahwa pada Putusan arbitrase, BPSK juga terdapat kendala dalam pelaksanaan permohonan eksekusi yang disebabkan tidak adanya pencantuman irah-irah "Demi Keadilan Berdasarkan Ketuhan Yang Maha Esa" pada putusan arbitrase BPSK tersebut (Fahmiron, 2018: 4).

Dari uraian Fahmiron diatas dapat ditarik kesimpulan, pada prinsipnya Putusan BPSK dapat di eksekusi melalui Pengadilan Negeri karena merupakan kekhususan dari pelaksanaan eksekusi secara umum menurut ketentuan hukum acara perdata sesuai dengan azas hukum lex specialis derogot legi generalis yang berarti bahwa ketentuan khusus menyampingkan ketentuan yang bersifat umum.

Adapun Tujuan Perlindungan Konsumen (Ganef Judawati, 2015: 1), antara lain adalah:

1. Terbangunnya konsumen yang lebih cerdas, kritis dan mandiri serta memiliki kesadaran bertindak baik untuk dirinya sendiri maupun lingkupnya. Dengan demikian setiap konsumen akan mampu menghadapi pasar yang semakin terbuka;

2. Terwujudnya pelaku usaha yang bertanggung jawab atau mampu menjalankan hak dan kewajibannya secara professional atau dapat mengedepankan etika bisnis, tertib mutu, tertib ukur, dan ikut menjaga kelestarian lingkungan (K3L) yang tidak merugikan konsumen.

Pelaksanaan Perlindungan menurut Undang-Undang Perlindungan Konsumen (Ganef Judawati, 2015: 1), adalah sebagai berikut:

1. Preventif: Pemberian perlindungan kepada konsumen sebelum yang bersangkutan mengalami kerugian atau menderita sakit akibat mengkonsumsi barang/jasa, (melakukan pengawasan barang dan/atau jasa beredar di pasar) Melalui peranan Badan Perlindungan Konsumen Nasional (BPKN), Lembaga Perlindungan Konsumen Swadaya Masyarakat (LPKSM), 
kontrol pra pasar melalui penerapan SNI, instrument perizinan, dan lainlain.

2. Represif: Pemberian perlindungan kepada konsumen sesudah yang bersangkutan mengalami kerugian atau menderita sakit akibat mengkonsumsi barang/jasa. melalui peranan BPSK, kontrol pasca pasar seperti pengawasan dan penerapan sanksi dan lainnya.

Sedangkan Lembaga Perlindungan Konsumen Swadaya Masyarakat (LPKSM), mempunyai tugas sebagai berikut:

- Menyebarkan informasi;

- Memberikan nasihat kepada konsumen;

- Membantu konsumen dalam memperjuangkan haknya;

- Menerima keluhan atau pengaduan konsumen;

- Bekerja sama dengan instansi terkait dalam upaya mewujudkan perlindungan konsumen;

- Melakukan pengawasan bersama pemerintah dan masyarakat terhadap pelaksanaan perlindungan konsumen ( Ganef Judawati, 2015: 1).

LPKSM di Indonesia saat ini yang terdaftar sebanyak 317 buah, namun demikian belum semuanya bekerja secara aktif ( Ganef Judawati, 2015: 10).

Berdasarkan keterangan Gusriwal Ketua BPSK Kota Payakumbuh, keberadaan BPSK Kota Payakumbuh yang dibentuk pada tahun 2015, menerangkan jumlah sengketa konsumen yang masuk pada BPSK Kota Payakumbuh sejak tahun 2016 sampai tahun 2108 adalah sebanyak 18 (delapan belas) sengketa dengan rincian sebagai berikut:

1. Tahun 2016, jumlah sengketa yang masuk 9 (sembilan), selesai dengan cara konsiliasi 7 (tujuh) sengketa, tidak selesai 2 (dua) sengketa.

2. Tahun 2017, jumlah sengketa yang masuk 7 (tujuh), selesai dengan cara mediasi 3 (tiga) sengketa, tidak selesai 4 (empat) sengketa.

3. Tahun 2018, jumlah sengketa yang masuk 2 (dua), selesai dengan cara mediasi 1 (satu) sengketa, selesai dengan cara mediasi 1 (satu) sengketa.

Bahwa dari hasil wawancara penulis dengan Gusriwal, dari sengketa konsumen yang telah diputus oleh BPSK Kota Payakumbuh dari kurun waktu 2106 sampai 2108 pada umumnya diselesaikan dengan cara konsiliasi sebanyak 3 (tiga) kasus, diputus dengan cara mediasi sebanyak 5 (lima) kasus sedangkan diselesaikan dengan cara arbitrase sebanyak 4 (empat) kasus.

Bahwa dari data-data yang dikemukakan diatas, ternyata pada tahun 2107, ada 4 (empat) sengketa yang tidak selesai dan menurut Gusriwal, sengketa yang tidak selesai tersebut disebabkan tidak adanya kesepakatan antara para pihak dalam menyelesaikan sengketa konsumen untuk diselesaikan oleh BPSK Kota Payakumbuh dan hal tersebut berdasarkan adalah hak bagi para pihak untuk tidak mau diselesaikan oleh BPSK 
dan menurut Gusriwal, tidak ada ketentuan yang mengatur tentang tugas dan tidak ada kewenangan BPSK sengketa tersebut harus di putus BPSK apabila para pihak tidak sepakat untuk menyelesaikan sengketa pada BPSK.

\section{Keberadaan Undang-Undang} Perlindungan Konsumen sebagai upaya hukum dimaksudkan untuk menjamin kepastian hukum ternyata belum cukup mampu memberikan perlindungan hukum kepada konsumen. Faktanya konsumen tetap saja dalam kedudukan dan posisi tawar yang lemah, seperti pelaku usaha membohongi konsumen melalui iklan, promosi yang dapat terjadi dalam bentuk pernyataan salah, pernyataan yang menyesatkan ataupun iklan yang berlebihan. Namun karena kedudukan pelaku usaha berada pada kedudukan yang lebih kuat dari konsumen (Sri Turatmiyah dan Arfiana Novera, 2016:12).

\section{Faktor-Faktor Yang Menyebabkan Terjadinya Penurunan Sengketa Yang Masuk Pada Kantor BPSK Kota Payakumbuh}

Berdasarkan hasil wawancara penulis dengan Dolly Rangga Putra, Sekretariat BPSK Kota Payakumbuh, faktor-faktor lain yang menyebabkan terjadinya penurunan sengketa konsumen pada BPSK Kota Payakumbuh secara garis besar adalah kapasitas pihak konsumen selaku Penggugat yang tidak berkapasitas sebagai konsumen akhir sehingga gugatan atau laporan yang masuk BPSK Kota Payakumbuh tidak bisa diterima atau ditolak karena penekanan sengketa konsumen yang bisa disidangkan pada BPSK adalah konsumen akhir bukan konsumen antara dan faktor-faktor lain yang menyebabkan tidak populernya BPSK dimata masyarakat konsumen di Kota Payakumbuh karena adanya peraturan tentang tugas dan wewenang hal mana BPSK lebih memilih berperan pasif karena BPSK memiliki juga kewenangan sebagai lembaga penyelesaian sengketa konsumen di luar pengadilan, sehingga BPSK hanya menunggu laporan dari konsumen yang merasa dirugikan oleh perbuatan pelaku usaha disamping sosialisasi yang masih dirasakan kurang karena keterbatasan anggaran.

Begitu juga hambatan-hambatan yang dihadapi oleh majelis BPSK dalam penyelesaian sengketa konsumen di BPSK Kota Payakumbuh juga disebabkan antara lain:

1. BPSK Kota Payakumbuh tidak memiliki kekuatan upaya paksa untuk menghadirkan pelaku usaha;

2. Pelaku Usaha yang tidak bersedia hadir di BPSK. meskipun dalam Undang-Undang Perlindungan Konsumen, BPSK dapat meminta bantuan dari Penyidik Umum (Polisi) namun dalam praktiknya sulit untuk dilaksanakan untuk menghadirkan pelaku usaha;

3. Pelaku Usaha mempunyai kebebasan untuk memilih tempat menyelesaikan perkara apakah melalui BPSK atau Pengadilan Negeri sebagai tempat untuk 
menyelesaikan Sengketa Konsumen (Pasal 45 ayat (2) UUPK),

4. Pelaku Usaha dapat menolak keinginan konsumen agar sengketanya diselesaikan di BPSK apabila para pihak sepakat memilih BPSK sebagai tempat untuk menyelesakan sengketa.

\section{SIMPULAN}

Berdasarkan pembahasan yang telah penulis bahas diatas mengenai peranan BPSK Kota Payakumbuh dalam menangani sengketa konsumen dengan pelaku usaha dan hasil penelitian yang penulis lakukan pada Kantor BPSK Kota Payakumbuh maka penulis dapat mengambil kesimpulan sebagai berikut:

1. Peranan BPSK Kota Payakumbuh setelah dibentuk pada tahun 2015 masih kurang dimanfaatkan dan dirasakan oleh masyarakat konsumen. Masih banyak masyarakat konsumen yang berdomisili di Kota Payakumbuh dan sekitarnya yang masih belum memanfaatkan BPSK sebagai lembaga pencari keadilan apabila konsumen tersebut merasa dirugikan oleh pelaku usaha. Dari rekapitulasi sengketa konsumen yang ada pada BPSK Kota Payakumbuh dari tahun 2016 sampai 2108, kasus yang masuk berjumlah 18 (delapan belas) kasus dan 4 (empat) kasus yang tidak selesai pada tahun 2017 karena para pihak tidak mau diselesaikan oleh BPSK Kota Payakumbuh.
2. Faktor-Faktor yang menyebabkan terjadinya penurunan sengketa yaitu: masih kurangnya sosialiasi tentang keberadaan BPSK Kota Payakumbuh walaupun pembentukan lembaga BPSK Kota Payakumbuh sudah ada berdasarkan SK Menteri Perdagangan pada tahun 2015

Di dalam mengemukakan saransaran terhadap keberadaan BPSK Kota Payakumbuh ini, agar peran dan kewenangan BPSK dapat dirasakan manfaatnya oleh masyarakat konsumen, maka penulis menyarankan sebagai berikut agar:

1. Perlunya revisi atau penggantian terhadap Undang-Undang Perlindungan Konsumen serta peraturan lain dibawahnya agar hakhak konsumen dan juga hak-hak pelaku usaha dapat dijamin secara baik oleh hukum hal mana UndangUndang Perlindungan Konsumen Nomor 8 tahun 1999 masih dirasakan banyak kekurangannya. Keberadaan Majelis Badan Badan Penyelesaian Sengketa Konsumen (BPSK) selaku pihak yang memutuskan sengketa konsumen hendaknya diberi kewenangan yang lebih luas sehingga konsumen dalam mencari keadilan dapat terpenuhi secara maksimal.

2. Hendaknya pihak Sekretariat Badan Badan Penyelesaian Sengketa Konsumen (BPSK) memberikan 
sosialisasi kepada masyarakat konsumen yang merasa hak-haknya dirugikan oleh pelaku usaha untuk melaporkan dalam bentuk gugatan pada BPSK dan yang paling penting adalah biaya gugatan tidak ada atau gratis

\section{UCAPAN TERIMA KASIH}

Segenap Puji dan Syukur penulis ucapkan ke hadirat Allah SWT yang telah memberikan Rahmat dan Karunia-Nya, serta salawat serta salam untuk Rasullulah Muhammad SAW, Alhamdulillah akhirnya penulis dapat menyelesaikan penulisan karya ilmiah ini yang diberi judul: "Peranan Badan Penyelesaian Sengketa Konsumen (BPSK) Kota Payakumbuh Terhadap Sengketa Konsumen "

Penulis menyadari bahwa karya ilmiah ini masih merupakan kupasan yang dangkal dan belum mendalam serta masih perlu perbaikan di sana sini dikemudian hari, dan karya ilmiah ini dapat diselesaikan dengan bantuan dan dorongan dari berbagai pihak yang tidak dapat penulis sebutkan satu persatu,Oleh karena itu pada kesempatan ini dengan segala kerendahan hati, penulis mengucapkan terimakasih dan penghargaan yang sebesar-besarnya kepada:
1. Bapak Dr. Eviandi Ibrahim S.H., M.Hum selaku Ketua Sekolah Tinggi Ilmu Hukum (STIH) Putri Maharaja Payakumbuh

2. Seluruh rekan-rekan Dosen Sekolah Tinggi Ilmu Hukum Putri Maharaja yang tidak dapat penulis sebutkan satu-persatu.

3. Bapak Gusriwal, SE selaku Ketua BPSK Kota Payakumbuh dan bapak Dolly Rangga, SE selaku sekretariat BPSK Kota Payakumbuh yang telah memberikan bahan-bahan serta datadata kepada penulis dalam rangka penyelesaian karya ilmiah ini.

\section{DAFTAR PUSTAKA}

Darmayanti, E. (2018). Perlidungan Hukum Terhadap Pelaksanaan Keselamatan Dan Kesehatan Kerja (K3) Pada Perusahaan. Jurnal Cendekia Hukum, 3(2), 283-296.

Desemberius, SE. MM, Penyelenggaraan Badan Penyelesaian Konsumen (BPSK), Bimtek BPSK se Sumbar di Padang, tanggal 03 Maret 2016.

Faisal. (2018). Perlindungan Hukum Bagi Konsumen Terhadap Pra Kepemilikan Rumah Sangat Sederhana Di Kota Payakumbuh. Jurnal Cendekia Hukum, 3(2), 178187.

Fahmiron, SH. M.Hum, Proses Pelaksanaan Eksekusi Putusan Badan Penyelesaian Sengketa (BPSK) di Pengadilan Negeri, Bimtek BPSK se Sumbar di Padang, tanggal 13 Maret 2018. 
Nedi Rinaldi: Peranan BPSK Kota Payakumbuh Terhadap Sengketa Konsumen

Fahmi Shabab, SE, MBL, Penyelesaian Sengketa pada di BPSK Melalui Mediasi, Bimtek BPSK se Sumbar di Padang tanggal 30 September 2015.

Ganef Judawati, Tujuan Perlindungan Konsumen, Bimtek BPSK se Sumbar di Padang, di Padang tanggal 30 September 2015.

I. Made Widyana, Alterantif Penyelesaian Sengketa (ADR), (Jakarta: Indonesia Business Law Center (IBLS) Bekerja sama dengan Kantor Hukum Gani Djemat \& Partners, 2007).

Sri Turatmiyah, A. N. (2016). Peran Badan Penyelesaian Sengketa Konsumen dalam Pengawasan Klausula Baku di Kota Palembang. Jurnal Hukum IUS QUIA IUSTUM, 32(1), 147-165.

Superry Daniel Sitompul, J. S. (2014). Peran Badan Penyelesaian Sengketa Konsumen (Bpsk) Dalam Penyelesaian Sengketa Konsumen Terkait Good Governance (Studi
Kasus di BPSK Kota Medan). Jurnal Mercatoria, 7(2), 208-221.

Zainul Akhyar, Harpani Matnuh, $\mathrm{H}$. (2015). Peranan Badan Penyelesaian Sengketa (Bpsk) Kota Banjarmasin. Jurnal Pendidikan Kewarganegaraan, 5(10), 773-783.

Undang- Undang Nomor 8 Tahun 1999 Tentang Perlindungan Konsumen (UUPK).

Keputusan Menteri Perindustrian dan Perdagangan Nomor: 350/MPP/ Kep/ 12/ 2001, tentang Pelaksanaan Tugas dan Wewenang Badan Penyelesaian Sengketa Konsumen disingkat BPSK.

Peraturan Menteri Perdagangan Nomor: 06/M-DAG/PER/2/2017, tentang Badan Penyelesaian Sengketa Konsumen. 